\title{
Estimasi Peluang Terjadinya Wabah DBD di Kota Pontianak Berdasarkan Tinjauan Cuaca Menggunakan Motede Jaringan Syaraf Tiruan
}

\author{
Renitania $^{1)^{*}}$, Joko Sampurno ${ }^{1)}$, Andi Ihwan ${ }^{1)}$
}

\author{
1) Program Studi Fisika, Fakultas Matematika dan Ilmu Pengetahuan Alam \\ Universitas Tanjungpura, Pontianak \\ *Email : welly_holic@yahoo.com
}

\begin{abstract}
Abstrak
Telah dilakukan estimasi peluang terjadinya wabah DBD berdasarkan tinjauan cuaca bulanan di kota Pontianak menggunakan Jaringan Syaraf Tiruan algoritma Hopfield. Pada penelitian ini objek pelatihannya adalah data unsur cuaca bulanan dari tahun 2004 - 2012. Unsur cuaca tersebut adalah data kelembaban udara, curah hujan, uap air dan suhu. Keempat data unsur cuaca tersebut diestimasi untuk menghasilkan nilai bobot (w) yang menghubungkan unsur cuaca dengan perkembangan wabah DBD. Dari hasil simulasi dihasilkan nilai bobot (w) yang baik yaitu -74,31 dan 39,22. Dengan nilai ketepatan estimasi $72 \%$ dari data observasi.
\end{abstract}

Kata Kunci: Jaringan Syaraf Tiruan, Metode Hopfield, DBD,Unsur Cuaca

\section{Pendahuluan}

Demam Berdarah Dengue (DBD) merupakan salah satu masalah kesehatan yang sangat serius di Indonesia. Penyakit DBD pertama kali ditemukan pada tahun 1968 di Surabaya dengan kasus 58 orang anak, 24 diantaranya meninggal dunia. Sejak itu penyakit DBD mulai menyebar di seluruh Indonesia (Achmadi, 2010). Penyakit DBD merupakan penyakit menular yang disebabkan oleh virus dengue yang dibawa oleh nyamuk Aedes aegypti, Aedes albopictus dan Aedes scultellaris. Jenis nyamuk Aedes aegypti merupakan faktor utama penyebaran penyakit DBD. Nyamuk ini berkembang pada suhu sekitar $28{ }^{\circ} \mathrm{C}$ (Cristopher, 1960). Seluruh wilayah Indonesia mempunyai resiko untuk terjangkit penyakit DBD, kecuali daerah yang memiliki ketinggian 1000 meter di atas permukaan laut (Fatih dan Wahyuni, 2005).

Kota Pontianak merupakan salah satu wilayah endemik DBD karena memiliki kondisi suhu udara cukup tinggi serta kelembaban udara yang tinggi. Menurut Peraturan Bupati Malang tentang pengendalian penyakit DBD suatu daerah dikatakan daerah endemis DBD apabila daerah tersebut selama tiga (3) bulan berturut-turut terjadi Kejadian Luar Biasa (KLB) (Peraturan Bupati Malang No.2 Tahun 2011).

Karena masalah kesehatan tersebut, perlu dilakukan penelitian untuk melihat berapa besar hubungan perilaku cuaca dengan vektor penyebab DBD yaitu nyamuk Aedes aegypti. Metode yang digunakan dalam penelitian ini adalah metode Jaringan Syaraf Tiruan (JST) (Eliyanti, 2005). Metode JST yang digunakan adalah algoritma Hopfield karena sangat baik dalam pola model keluaran dengan bentuk kriteria. Algoritma tersebut dimanfaatkan untuk mencari nilai bobot (W) yang akan dikalikan dengan unsur-unsur cuaca sehingga dapat memodelkan kriteria wabah DBD atau tidak.

\section{Landasan Teori}

\subsection{Jaringan Syaraf Tiruan}

Jaringan Syaraf Tiruan adalah paradigma pemrosesan suatu informasi yang terinspirasi oleh sistem sel syaraf biologi, sama seperti otak yang memproses suatu informasi. Elemen mendasar dari paradigma tersebut adalah struktur yang baru dari sistem pemrosesan informasi. JST seperti manusia, belajar dari suatu contoh. JST dibentuk untuk memecahkan suatu masalah tertentu seperti pengenalan pola atau klasifikasi karena proses pembelajaran (Eliyanti, 2005).

Sejumlah sinyal masukkan (a) dikalikan dengan masing-masing penimbang yang sering disebut dengan bobot (w). Seluruh hasil perkalian tersebut dijumlahkan dan keluarannya dimasukkan ke dalam fungsi pengapit untuk mendapatkan tingkatan derajat sinyal keluaran.

\subsection{Metode Hopfield}

Hopfield merupakan metode JST yang menggunakan satu layar (single layer). Metode ini dikembangkan oleh ahli fisikawan John Hopfield dan David Tank pada tahun 1982. Metode Hopfield ini bersifat unsupervised learning (pembelajaran tak terawasi) yaitu JST yang tidak memiliki data atau contoh pelatihan sehingga dalam prosesnya jaringan ini akan 
mengorganisasikan dirinya sendiri sehingga membentuk vektor-vektor input yang serupa.

Dalam prosesnya metode Hopfield bersifat asynchrous updating, artinya pada suatu saat hanya satu unit (neuron) yang memperbaharui aktivasi (Prima dkk, 2010). Metode Hopfield identik dengan matrik simetris. Secara umum, nilai output JST ditentukan oleh nilai input, bobot (weight) dan fungsi aktivasinya. Bentuk aktivasi dipilih berdasarkan masalah yang akan diselesaikan. Bila jaringan Hopfield yang dirancang untuk melakukan klasifikasi pola biner-pola maka digunakan step function dengan dua nilai (0 dan 1). Namun bila jaringan Hopfield yang dirancang pola bipolar maka step function yang digunakan adalah nilai (-1 dan 1$)$ (Ernawati, 2009).

\subsection{Perkembangan Nyamuk Aedes aegypti}

Nyamuk Aedes aegypti adalah nyamuk penyebab penyakit DBD. Nyamuk ini hidup sangat baik di daerah tropis, terutama hidup dan berkembang biak di dalam rumah yaitu di tempat penampungan air jernih atau tempat penampungan di sekitar rumah. Nyamuk jenis ini dapat berkembang biak sangat baik pada suhu $28{ }^{\circ} \mathrm{C}$, dimana tingkat kelembaban udara yang sangat tinggi kerena pengaruh banyaknya curah hujan dan dikombinasikan dengan temperatur tersebut tidak hanya akan memperpanjang umur nyamuk tetapi juga mendukung aktivitas nyamuk secara keseluruhan (Christopher, 1960). Umur nyamuk yang lebih panjang tentunya akan meningkatkan peluang bagi virus dengue untuk menyelesaikan masa inkubasi ekstrinsiknya.

Demam Berdarah Dengue (DBD) adalah penyakit infeksi akut yang disebabkan oleh virus dengue yang dibawa oleh nyamuk Aedes aegypti betina (Peraturan Bupati Malang No.2, 2011). Penyakit DBD pertama kali ditemukan pada tahun 1968 di Surabaya dengan kasus 58 orang anak, 24 diantaranya meninggal dengan Case Fatality Rate $(\mathrm{CFR})=41,3 \%$. Sejak itu penyakit DBD menunjukkan kecenderungan peningkatan jumlah kasus dan luas daerah terjangkit. Seluruh wilayah Indonesia mempunyai resiko untuk terjangkit penyakit DBD, kecuali daerah yang memiliki ketinggian lebih dari 1000 meter di atas permukaan laut (Fatih dan Wahyuni, 2005).

\subsection{Hubungan Perkembangbiakan Nyamuk Penyebab DBD Terhadap Faktor Cuaca}

Asia Tenggara merupakan daerah beriklim tropis dan memiliki lokasi di zona equatorial tempat dimana Aedes aegepty menyebar secara merata baik di pedesaannya maupun di perkotaannya. Di Indonesia virus dengue memiliki siklus epidemik setiap 9-10 tahun. Siklus ini terjadi karena perubahan iklim sehingga berpengaruh terhdap kehidupan nyamuk tersebut. Menurut Mc Michael, perubahan iklim menyebabkan perubahan curah hujan, kelembaban suhu, arah angin sehingga berpengaruh terhadap ekosistem daratan maupun ekosistem laut serta berpengaruh terhadap kesehatan terutama terhadap perkembangan penyakit seperti nyamuk Aedes aegypti, malaria dan lainnya (Sidiek, 2012).

Iklim dapat berpengaruh terhadap pola penyakit infeksi karena agen penyakit baik virus, bakteri atau parasit dan vektor bersifat sensitif terhadap suhu, kelembahan, curah hujan, lama penyinaran matahari dan kecepatan angin (Majidah dkk, 2010). Walaupun iklim dapat berpengaruh terhadap penyebaran dan perkembangan DBD, namun tidaklah menjadi faktor utama terjadinya wabah DBD, faktor lingkungan dan prilaku masyarakat juga sangat berpengaruh terhadap perkembangan wabah DBD.

\section{Metodologi \\ 3.1 Data}

Data yang digunakan dalam penelitian ini adalah data sekunder bulanan kelembaban udara, curah hujan, uap, suhu dan data jumlah pasien DBD yang ada di Kota Pontianak, Kalimantan Barat. Data kelembaban udara, curah hujan, uap dan suhu diperoleh dari Badan Meteorologi Klimatologi dan Geofisika (BMKG) Supadio Pontianak, sedangkan data jumlah pasien DBD diperoleh dari Rumah Sakit Sudarso dan Rumah Sakit Antonius.

\subsection{Prosedur Penelitian}

Data unsur cuaca dan jumlah pasien DBD tersebut akan diproses melalui beberapa langkah sebagai berikut :

a. Penentuan Karakteristik

Data kelembaban udara, curah hujan, data uap dan suhu digunakan sebagai data estimasi. Data tersebut akan digunakan untuk mengklasifikasikan terjadinya wabah DBD atau tidak pada suatu waktu. Penentuan karakteristik terjadinya wabah atau tidaknya bergantung pada data jumlah pasien DBD yang diperoleh dari Rumah Sakit Sudarso dan Rumah Sakit Antonius.

b. Penentuan Nilai Bipolar

Untuk memudahkan dalam proses penginputan data maka data unsur-unsur cuaca yang telah diklasifikasikan dalam dua kriteria wabah atau tidak wabah tersebut diubah terlebih dahulu menggunakan fungsi aktivasi bipolar yaitu fungsi dimana angka 
yang ditunjukan hanya nilai 1 atau -1. Nilai tersebutlah yang akan menjadi target yang akan dicapai.

c. Pembuatan Model Simulasi

Pembuatan simulasi diperlukan untuk melakukan penyesuaian nilai bobot dengan nilai target (keluaran) yang diinginkan sehingga akan menghasilkan bobot optimal mencapai konvergen yang bisa mengenali data uji.

d. Validasi

Validasi ini dilakukan untuk memastikan apakah model yang telah diestimasi tersebut merupakan model terbaik atau bukan dengan cara keakuratan output yang dihasilkan. Rumus validasinya :

$$
\theta=\frac{\sum X_{t}}{\sum X_{o}} x 100 \%
$$

Dimana $\theta=$ tingkat ketepatan (\%)

$X_{t}=$ data hasil simulasi yang benar

$X_{o}=$ data kondisi cuaca sebenarnya

Berikut ini adalah tabel nilai koefesien tingkat ketepatan.

Tabel 1 Skor Penilaian Data Hasil Validasi

\begin{tabular}{ll}
\hline \multicolumn{1}{r}{ Kategori } & \multicolumn{1}{c}{$\begin{array}{c}\text { Nilai Tingkat } \\
\text { Ketepatan }\end{array}$} \\
\hline Istimewa & $91-100 \%$ \\
Sangat Baik & $81-90 \%$ \\
Baik & $71-80 \%$ \\
Cukup Baik & $61-70 \%$ \\
Kurang Baik & $51-60 \%$ \\
Sangat Kurang & $<50 \%$ \\
\hline
\end{tabular}

(Sumber : Irmawan dan Herusantoso, 2011)

\section{Hasil dan Diskusi}

Penelitian ini menggunakan JST algoritma Hopfield untuk memprediksikan keadaan wabah atau tidak wabah Demam Berdarah Dengue (DBD) di Kota Pontianak berdasarkan unsurunsur cuaca yaitu kelembahan udara, curah hujan, uap dan suhu udara.

\subsection{Penentuan Kriteria}

Hasil dari penelitian ini dikriteriakan dalam dua (2) kriteria yaitu wabah dan tidak wabah. Observasi dilakukan dengan mengkolerasikan data jumlah pasien DBD dengan keempat unsur cuaca yaitu kelembaban udara, curah hujan, uap dan suhu udara bulanan. Data yang dijadikan data observasi adalah data sekunder selama 9 tahun dari tahun 2004 - 2012. Sedangkan penentuan terjadi wabah dan tidak wabah dikaji selama 3 bulan berturut-turut dalam kurun waktu 2 tahun dengan melihat waktu-waktu terjadinya peningkatan jumlah pasien

Dari hasil observasi data jumlah pasien DBD dengan keempat unsur cuaca tersebut dibuatlah tabel kriteria unsur cuaca terjadi wabah dan tidak wabah sebagai berikut :

Tabel 2 Rancangan Kriteria Unsur Cuaca

\begin{tabular}{lll}
\hline \multicolumn{1}{c}{ Unsur Cuaca } & \multicolumn{1}{c}{ Wabah } & Tidak Wabah \\
\hline Curah Hujan & $<185 \mathrm{~mm}$ & $>402 \mathrm{~mm}$ \\
Kelembaban & $>124 \%$ & $<102 \%$ \\
Uap Air & $<83 \mathrm{~mm}$ & $>87 \mathrm{~mm}$ \\
Suhu & $>27 \mathrm{C}^{\circ}$ & $<260^{\circ} \mathrm{C}$ \\
\hline
\end{tabular}

Rancangan kriteria unsur cuaca tersebut kemudian diubah ke dalam rancangan kriteria unsur cuaca bipolar dengan menggunakan fungsi aktifasi bipolar yaitu dengan nilai target keluaran menunjukan nilai -1 dan 1.

Dibawah ini adalah tabel rancangan kriteria unsur cuaca bipolar.

Tabel 3 Kriteria Unsur Cuaca Bipolar

\begin{tabular}{lrc}
\hline Unsur Cuaca & Wabah & Tidak Wabah \\
\hline Curah Hujan & -1 & 1 \\
Kelembaban & 1 & -1 \\
Uap Air & -1 & 1 \\
Suhu & 1 & -1 \\
\hline
\end{tabular}

\subsection{Pembuatan Simulasi Algoritma}

Input dalam asitektur Hopfield pada penelitian ini menggunakan 4 (empat) unsur cuaca sebagai neuronnya. Dalam jaringan Hopfield semua neuron berhubungan penuh, maksudnya adalah output dari neuron yang satu dijadikan input kembali untuk semua neorun yang lain.

Pembobotan dalam jaringan syaraf tiruan Hopfield ini menggunakan matriks simetris dengan diagonal utamanya bernilai nol, seperti pada gambar matriks dibawah ini :

$$
\left[\begin{array}{llll}
0 & a & b & a \\
a & 0 & a & b \\
b & a & 0 & a \\
a & b & a & 0
\end{array}\right]
$$

dengan kata lain setiap neuron tidak dapat memberi input bagi dirinya sendiri.

Gambar 4.1 menunjukan dari rancangan model asitektur jaringan syaraf tiruan Hopfield untuk keempat unsur cuaca dengan target kriteria terjadinya wabah DBD atau tidak.

Pada jaringan Hopfield output setiap neuron dijadikan umpan balik kepada input dari neuron-neuron yang lainnya melalui bobot koneksi $\mathrm{W}_{\mathrm{ij}}$ yang tetap. Nilai $\mathrm{W}_{\mathrm{ij}}$ mula-mula diinisialisasikan menggunakan algoritma Hopfield untuk sebuah pola yang masuk. Pola yang tidak dikenal (bobot awal) dimasukkan ke dalam jaringan sekali saja pada waktu kondisi nol, kemudian jaringan akan beriterasi sampai pada iterasi yang sudah ditentukan dan menghasilkan output yang konvergen.

Output dikatakan konvergen apabila nilai output yang dihasilkan tidak berubah sampai 
iterasi selesai. Output yang konvergen inilah yang merupakan output JST atau target yang akan dicari.

Berikut ini adalah tabel pembobotan yang digunakan dalam penelitian ini :

Tabel 4 Pemilihan Bobot

\begin{tabular}{cccc}
\hline \multirow{2}{*}{ No } & \multicolumn{2}{c}{ Bobot } & Keterangan \\
& $\mathrm{a}$ & $\mathrm{B}$ & Wabah \\
\hline 1 & $-8,14$ & 9,05 & $69 \%$ \\
2 & $-1,26$ & 9,13 & $70 \%$ \\
3 & $-2,78$ & 5,46 & $67 \%$ \\
4 & $-74,31$ & 39,22 & $72 \%$ \\
5 & $-76,55$ & 79,52 & $70 \%$ \\
\hline
\end{tabular}

Berdasarkan tabel 4 dapat dilihat bobot yang paling baik adalah pada saat bobot 74,3132 dan 39,2227 yaitu ketepatannya mencapai $72 \%$.

\subsection{Validasi Hasil Model dengan Data Observasi}

Berdasarkan persentase ketepatan hasil program pada penelitian ini, program ini dapat digunakan untuk melihat hubungan dinamika cuaca dengan perkembangan penyakit DBD. Output yang dihasilkan program ini menunjukkan ketepatan pada kejadian wabah sebenarnya. Namun ada beberapa data ketika divalidasikan menunjukkan kesalahan, seperti pada data ke-8 yaitu bulan Agustus tahun 2004 nilai output dari program ini menunjukkan nilai untuk kriteria wabah, sedangkan dari data yang diperoleh di dua rumah sakit yaitu Rumah Sakit Antonius dan Rumah Sakit Sudarso menunjukan data pada saat itu tidak terjadi wabah. Ketidaksesuaian hasil validasi dari program ini dapat disebabkan beberapa faktor:

Pertama; kurang tepatnya dalam menentukan batas-batas untuk setiap unsur cuaca yang dijadikan data estimasi.

Kedua; data yang dijadikan data observasi adalah data jumlah pasien di dua rumah sakit yaitu Rumah Sakit Antonius dan Sudarso. Pasien dikedua rumah sakit tersebut adalah gabungan dari pasien kota Pontianak dan luar kota Pontianak, sedangkan data unsur cuaca yang dikaji adalah data unsur cuaca Kota Pontianak saja.

Ketiga; kurangnya referensi yang detail tentang siklus hidup nyamuk penyebab DBD ini serta tidak adanya standar baku berapa jumlah pasien DBD yang masuk dalam kategori KLB.

\section{Kesimpulan}

Dari penelitian diketahui bahwa persentase validasi ketepatan hasil output model dengan data observasi menunjukan nilai $72 \%$. Nilai tersebut menunjukkan kriteria baik, sehingga dapat digunakan untuk estimasi peluang munculnya penyakit DBD dengan meninjau unsur-unsur cuaca yang digunakan.

Output yang dihasilkan untuk kriteria wabah DBD adalah -1 1 - -1 1, nilai ini sesuai dengan nilai output yang ditargetkan. Sedangkan untuk nilai 1111 berdasarkan hasil validasi menunjukkan kriteria tidak wabah, sehingga kombinasi angka tersebut dikategorikan tidak wabah.

\section{Pustaka}

Achmadi, U.F, 2010, Manajemen Demam Berdarah Berbasis Wilayah, Buletin Jendela, Bakti Husada.

Christophers, SR., 1960, Aedes Aegypti (L.) The Yellow Fever Mosquito. Its Life History, Bionomics and Structure, Cambridge University Press, Page 550-554.

Eliyanti, 2005, Pengantar Jaringan Syaraf Tiruan, http. MateriKuliah.Com, Indonesia.

Ernawati, Septima, 2009, Aplikasi Hopfirld Neural Networks Untuk Perkiraan Cuaca, Stasiun Klimatologi Semarang.

Fatih, S.K dan Charatina Umbol Wahyuni, 2005, Peranan Faktor Lingkungan dan Perilaku Terhadap Penolakan Demam Berdarah Dengue di Kota Mataram, Universitas Airlangga.

Irmawan D, Herusantoso, K., 2011, Penerapan Logika Fuzzy Sebagai Sistem Pendukung Keputusan Prakiraan Cuaca, e-Indonesia Initiative 2011 (eII2011) Konferensi Teknologi Informasi dan Komunikasi untuk Indonesia 14-15 Juni 2011, Bandung. Hal: 214-223

Majidah, Amah, V.D dkk, 2010, Faktor Iklim Dan Insiden Demam Berdarah Dengue Di Kabupaten Serang, Skripsi S1 Fakultas Kesehatan Masyarakat Universitas Indonesia, Depok.

Peraturan Bupati Malang No. 2 Tahun 2011 Tentang Pengendalian Penyakit Demam Berdarah Dengue di Kabupaten Malang.

Sidiek, Aboesina, 2012, Hubungan Tingkat Pengetahuan Ibu Mengenai Penyakit DBD Terhadap Kejadian Penyakit DBD Pada Anak, Universitas Diponegoro, Semarang. 